Akdeniz Kadın Çalışmaları ve

Toplumsal Cinsiyet Dergisi

http://dergipark.gov.tr/ktc

Sayı III (2) 213-232

Araştırma Makalesi

\title{
Türkiye'de Kuma Evliliklerinin Nedenleri Üzerine Sosyolojik Bir Analiz: Hatay-Samandağ Örneği
} Sociological Analyses on Reasons of Co-wife Marriages in Turkey: Hatay-Samandağ Examples

\author{
Hasan Şen* Kezban Gümüş **
}

Öz: Evli erkeklerin mevcut eşinin üzerine başka bir kadınla gayriresmî olarak evlenmesi olarak tanımlanan kumalık dünyada ve Türkiye'de eskiye oranla sayısal olarak azalma gösterse de bazı bölgelerde hâlâ görülebilmektedir. Söz konusu evliliklerin başta ekonomi, göç, eğitim eksikliği, toplumsal cinsiyet ve geleneksel değerler olmak üzere birçok nedeni bulunmaktadır. Bu çalışmada bir toplumsal olgu/sorun olan kuma evliliklerinin nedenleri Hatay ili Samandağ ilçesi örneği üzerinden analiz edilmiştir. Çalışmada nitel araştırma yöntemi ve derinlemesine görüşme tekniği kullanılmıştır. 16 ilk eş ve 16 kuma olmak üzere toplamda 32 kadınla görüşülmüştür.

Anahtar Kelimeler: Kumalık, Evlilik, Ataerkil Zihniyet, Poligami, Polijini.

Abstract: Co-wife marriages can be defined as the informal marriage of a married man to another woman besides his first wife. Such marriages can still exist in the world and in some parts of Turkey despite declining numbers. Economy, migration, lack of education, gender and traditional values lie at the root of them. In this study, co-wife marriages, which is a social notion and a problem in Turkey, were analyzed through Hatay province, Samandağ district. Qualitative method and in-depth interview technique were used in this study. Among 32 women interviewed in the study, 16 of them are first wives and 16 of them are coviwes.

Keywords: Co-Wife Marriages, Marriage, Patriarchal Mindset, Poligamy, Polygyny.

\section{Summary}

Polygamy is in existence in some parts of Turkey and the world. This phenomenon has a variety of reasons. These reasons may have general and specific contents when society is taken into consideration. The economy, for instance, can be regarded as a general reason. . Women with difficult economic situationsmay prefer to be a co-wife. However, reasons based on traditions are regarded as particular to the society. The causes of polygamy in Turkey are analyzed in this article.

\footnotetext{
*Doç. Dr., Muğla Sitkı Koçman Üniversitesi, Edebiyat Fakültesi, Sosyoloji Bölümü. senhasan@mu.edu.tr, ORCID: 0000-0003-2111-2223

** Sosyolog, Kiz1lay, kezbangumus2014@hotmail.com, ORCID:0000-0001-9200-3468
} 
The study was carried out in Hatay province and Samandağ district. A total number of 32 women were interviewed in this study. 16 of them are first wives and 16 of them are co-wives. In this research, a qualitative research method and in-depth interview technique were applied. In-depth interviews took about 45 minutes. Turkish, Kurdish, and Arabic languages were used in the interviews. There are many reasons for polygamy. Douglas R. White and Michael L. Burton, in their important article titled "Causes of Polygyny: Ecology, Economy, Kinship, and Warfare," in 1988, reasons are listed as follows: War, lack of education, migration, economic causes, population balance, religion, and culture. Other factors such as labor and property relations based on heritage and household economy, desire for power and reputation, psychological, traditional, patriarchal mentality, gender, and war can also play a role in polygamy. Theoretically, the reasons why polygamy is seen in Turkey are as follows: The first reason is the patriarchal social structure, which is both a general and a specific reason. The second reason is education. The low level of education of both men and women is very effective in the mentioned marriages. The third reason is that families have too many children. Having too many children causes economic difficulties. The women who live in this family face difficulties. This situation brings them to escape from this problem through marriage. On the other hand, the desire to have a boy motivates men to marry another woman. The fourth reason is the social environment and kinship relations. The rate of cowife marriage among relatives is high. The fifth reason is the "workforce" required in the household economy. Men benefit from women's labor force by using polygamy. The sixth reason is religious and traditional beliefs. Having a religious marriage experience in particular and social acceptance of it are important in these marriages. The last reason is the fear of not getting married. Women who are late about marrying can accept being a co-wife. The research has reached conclusions regarding the causes of polygyny: Women generally have a low level of education. This leads them to this kind of marriage. The economic situation of women before marriage is not good. Most of the women lived in a family with many children. Economic deficiencies and low income cause these marriages. Thoughts about being late to marry push women to become second wives. Age of marriage for women participants who accepted to be the co-wives is above the average age in Turkey. Another reason is that polygyny is common in the region where women live. This provides social legitimacy to marriages. The desire to benefit from women's free labor causes polygyny. most women do housework.. Society does not see co-wife marriages as a problem. They regard it as normal. Community pressure is a very important reason for these marriages. The participants expressed that the pressures coming from the social environment were effective to make this decision. 


\section{Giriş}

Tarihte çok farklı şekiller alan aile ve evlilik olgusu değişen sosyolojik koşullar altında daima evrim geçirmektedir. Örneğin eski çağlarda çeşitli nedenlerle poligami yani çok eşlilik daha sık görülse de günümüzde ağırlıklı olarak tek eşlilik tercih edilmektedir. Bunda da modern dünyanın dayandığı üretim biçimi, bireyselleşme olmak üzere birçok faktör rol oynamaktadır. Fakat bu durum poligaminin tümüyle ortadan kalktığı anlamına gelmemektedir. Nitekim poligami dünyada bazı ülkelerde ve Türkiye'de bazı bölgelerde ve illerde varlığını hâlâ sürdürmektedir.

Bir erkeğin evli olduğu halde ikinci bir kadınla gayriresmî olarak evlenmesi olarak tanımlanan kuma evliliği, genel olarak poligami çok eşlilik özel olarak da polijini/çok karılıkeşlilik içinde yer almaktadır. Birden çok kadının bir erkekle evlilik yaşaması aslında kadının doğal olmayan bir tanzimidir. Bozkurt Güvenç'in (1993:46) ifade ettiği gibi, dişi/erkek cinsiyet oranı “doğal ve evrensel olarak eşit veya denk olduğu için, fazla eş son derece sınırlıdır. Kuma, "açıkta (eşsiz) kalmış kadınların, paylaşılması değil yeniden dağıtımıdır” (Güvenç, 1993: 46). Sözü edilen dağıtım basit bir sayısal dengesizlik değil, nedenleri ve sonuçları itibariyle kadınlarda derin travmalara ve toplumsal cinsiyet eşitsizliğine yol açması nedeniyle sosyolojik olarak analiz edilmesi gereken çok önemli bir konudur. Bu nedenle bu evlilikleri ele alan bu çalışma, sözü edilen evliliklerinin gerisinde yatan ve onu yeniden üreten nedenleri ortaya koymayı amaçlamaktadır.

Bu çalışmada öncelikle kuma evliliklerinin teorik ve kavramsal arka planı ele alınacaktır. Ardından çalışmanın yöntemsel modeline yer verilecektir. Son olarak sözü edilen evliliklerin nedenleri katılımcıların görüşleri göz önünde tutularak sosyolojik olarak analiz edilecektir.

\section{Kuma Evliliklerine Teorik Bakış}

Tarihten bu yana farklı toplumsal koşulların etkisiyle çeşitli aile ve evlilik türlerine rastlanmaktadır. Zaman içinde ortaya çıkan değişimlere koşut olarak da aile ve evlilik türleri de değişmektedir. Dahası aile ve evlilik türlerine dair yapılan teorik yaklaşımlar da farklılık göstermektedir. Nitekim bu konu, Friedrich Engels'in şikâyet ettiği üzere tarihsel bir perspektiften kopuk ve parçalı analizlerle ele alınmış, bu da evliliğin ekonomi, kültür ve ideoloji gibi bileşenlerden muaf olarak algılanmasını beraberinde getirmiştir. Bunu önlemek adına Engels, tarihsel ve toplumsal şartlardan yüksek oranda etkilenen evliliklerin "tarihsel ardışıklık" dikkate alınarak değerlendirilmesini salık vermektedir. Buna göre tarihte evliliklerin en genelde "grup evlilikleri”, “çok eşli evlilikler” ve "tek eşli evlikler" şeklinde evrim geçirdiğini belirtmektedir (Engels, 2003: 10-11). Engels'in de ifade ettiği gibi modern dünyada tek eşlilik daha yaygın hale gelse de çok eşlilik yani poligami geçmişte yaygın olarak görülmektedir. Çalışmanın temel 
yörüngesini kaybetmemek adına burada sözü edilen tarihsel değişime detaylı olarak yer verilmeyecek, daha ziyade kumalık olgusuyla ilişkili boyutlarına ve kavramlara değinilecektir.

Önal Sayın, Aile Sosyolojisi adlı çalışmasında, tarihte "değiş tokuş yoluyla, satın alma yoluyla, kaçırma yoluyla, görücü usulüyle, anlaşma yoluyla ve tercihi yolla" olmak üzere çeşitli evliliklerin yapıldığını ifade etmektedir. Sayın’a göre, anaerkil dönemde daha yoğun görüldüğü şekliyle bir kadının birden fazla erkekle evlenmesi olarak tanımlanan çok kocalık, kavramsal karşılığı ile poliandri (polyandrie) ve daha ziyade ataerkil kültürlerde bir erkeğin birden fazla kadınla evlenmesi olan çok karılık yani polijini (polygynie) genel olarak çok eşlilik (poligamie) içinde yer almaktadır. Çok eşlilik tarih boyunca farklı geleneksel kodlar içinde uygulanagelmiştir. Söz konusu evlilik, görüldüğü toplumlarda değişik şekillerde meşrulaştırılmış ve onaylanmıştır. Örneğin, "Kikouyu kabilesinde bir kadın, Neden bu işleri ben yapmak zorunda kalıyorum? Neden kendine başka bir kadın almıyorsun? şeklindeki serzenişleri ile eşinin başka bir kadınla evlenmesini teşvik edebiliyordu”. Yine Afrika'da bir poligami örneği olarak tüm kadınların kendilerini kralın doğal eşleri olarak gördüğü de bilinmektedir (Sayın, 2020: 25;28, 227-239; 245-246).

$\mathrm{Bu}$ çalışmanın konusunu teşkil eden kuma evlilikleri polijini içinde değerlendirilmektedir (Eyce, 2000: 225). Polijini evliliklerinin dünyada hem görüldüğü toplumların kendine has koşullarının devreye girmesinin bir sonucu olarak genel hem de özel nedenleri olabilmektedir. Nitekim konuya dair olarak Douglas R. White and Michael L. Burton'un, 1988 y1lında yayınladıkları "Causes of Polygyny: Ecology, Economy, Kinship, and Warfare" adlı çok önemli makalede, tarihte ve günümüzde polijinin genel nedenlerine dair olarak farklı çalışmalardan hareketle derledikleri faktörlerin çokluğu dikkat çekmektedir. Sözü edilen evliliklerde savaş, eğitim, göç, ekonomi, nüfus dengesi, din ve kültür gibi faktörler etkili olmaktadır. Yine örneğin miras ve hane içi ekonomiye dayalı emek ve mülkiyet ilişkileri, güç ve itibar arayışı, psikolojik, geleneksel, toplumsal cinsiyet ve savaş gibi diğer faktörler de rol oynayabilmektedir. Buradan hareketle White ve Burton, genel bir kanı olarak kabul gördüğü şekliyle polijinin "sadece erkeğin libidosu ile ilişkilendirilmesinin sosyolojik koşullar dikkate alındığında basit ve kolaycı bir tez olduğu" düşüncesini dile getirmektedirler (White ve Burton, 1988: 881-887). Çünkü polijiniyi üreten çok fazla faktör vardır. Şimdi burada polijininin Türkiye'deki nedenlerini anlamak adına, onun oluşumuna kaynaklık eden nedenlere daha detaylı olarak bakmakta yarar var.

Polijini konusunda çalışmalar yapan antropologlardan biri olan Gery R. Lee, polijiniyi, tarihte daha yoğun olarak görüldüğü avcılık ve toplayıcılık döneminde av esnasında erkeklerin yırtıcı hayvanlar tarafından öldürülmesi sonucunda azalan erkek nüfusu ile ilişkilendirir. Lee'ye 
göre sözü edilen dönemde kadınların birden fazla erkekle evlenmesi bir tür demografik zorunluluk olarak görülmüştür (Lee, 1979: 706-711).

George Peter Murdock, polijininin ortaya çıkmasında ve yeniden üretilmesinde özellikle "kadınların erkeklere göre ekonomik ve sosyal olarak daha düşük seviyede tutulduğu ataerkil yaşamın uygun şartlar barındırdığını" ileri sürmektedir. "Çok eşliliğe elverişli olan her şeyin de ataerkil yaşamın gelişimini desteklediğini”, bu çerçevede "İslam’ın bu tür bir ataerkil yapıyı destekleyen bir etkiye sahip olduğunu" ifade etmektedir. Diğer yandan, geçmişte özellikle savaşların bir sonucu olarak kazanan tarafın yendiği tarafın mensuplarını (tabi ki kadınları ve çocukları) köleleştirdiğini söyleyen Murdock, sözü edilen uygulamanın erkeklerin toplumsal nüfuzunu ve statüsünü arttırdığına, kadınların köle olarak alınıp satılmasının yolunu açtığına ve ataerkil kültüre hizmet eden mülkiyet anlayışıyla desteklendiğine işaret etmektedir (Murdock, 1964: 206-207).

Amira Grossbard, polijinin bir nedeni olarak ekonomik faktöre dikkat çekmekte ve "poligaminin ve özelde polijinin, gelir elde etmek gibi ekonomik temelli bir rasyonel kararın” sonucu olduğu hipotezini Maiduguri örneğinde test etmektedir. Buna göre, evli erkekler, hane içi işlerde ve aile işçiliği yoluyla kadınların gelirlerinden yararlanabilmektedirler. Fakat kadınların ev dışında çalışmadıkları/veya çalışamadıkları için hem erkeklerin kadınların iş gücünden hem de bizatihi kadınların kendi ücretli işgüçlerinden yararlanamadıklarını belirtmektedir (Grossbar, 1976: 701-707).

Savaş ve polijini arasında ilişki kuran Melvin Ember ise, tarihsel süreçte ve kısmen günümüzde, özellikle savaş zamanlarında yüksek erkek ölümleri nedeniyle toplumlarda cinsiyete dayalı demografik dengesizlik meydana geldiğini ifade etmektedir. Bu durumda erkeklerin eşsiz kalan kadınları ikinci veya üçüncü eş olarak aldıkları görülmektedir (Ember, 1974: 199). Yine Stanley Witkowski, Melvin ve Carol Ember, çok eşlilik ve erkekler için gecikmiş evlilik arasında anlamlı ilişkiler bulmaktadır (White ve Burton, 1988: 871 ve Ember, 2007: 431;437). Burada şu noktaya önemle dikkat çekmek gerekir ki erkeklerin geç evliliklerinin polijinin bir nedeni olduğu şeklindeki bu tezin, kadınlar için geçerliliğinin sınandığı bir çalışmaya şimdilik rastlanılmamıştır.

Görüldüğü üzere dünyanın çeşitli bölgelerinde varlığını sürdüren polijininin çeşitli nedenleri vardır. Tabii ki bu genel nedenlerin yanında polijinin görüldüğü yerlerin başta sosyokültürel faktörler olmak üzere kendine has özel nedenleri de olabilmektedir. Buradan hareketle şimdi önce polijinin Türkiye'deki durumuna ve buna neden olan faktörlere bakalım. 


\section{Türkiye'de Evlilik ve Kumalık Olgusu}

Bu çalışmanın yapıldığı Türkiye'de de çeşitli aile ve evlilik türlerine rastlanmaktadır. Konuya dair olarak detaya girmeden İbrahim Yasa'nın yaptığı sınıflandırmayı hatırlayalım. Yasa’ya göre, “çekirdek aile; alamancı ailesi; kasaba ailesi; taygeldi ailesi; gecekondu ailesi ve köy ailesi” en sık görülen aile tiplerindendir. Evlilikler arasında da başta görücü usulü olmak üzere çeşitli türden evlilikler vardır. Kız kaçırma yoluyla ve kuma evlilikleri bunlardan biridir (Yasa, Toplumbilim Ders Notlar'indan Aktaran Kongar, 1993: 216).

Osmanlı döneminde daha yaygın olarak görülen kuma evlilikleri, taaddüd-i zevcat olarak tanımlanan poligami içinde yer almıştır. Osmanlı döneminde aile hukuku İslâm aile hukukuna dayandığından, polijini geleneksel ve dinsel olarak kendine destek bulabilmiştir. Türkiye Cumhuriyeti'nde 1926 yılında çıkarılan medeni kanun ile poligami, yerini tek eşlilik olan monogamiye bırakmıştır. Bu yasa ile evlilikte kadın erkek eşitliği, evlenme için devlet tarafından görevlendirilmiş memur bulunması şartı ve eşlerin ancak mahkeme kararıyla evlenme akdini sonlandırabilmeleri kuralları getirilmiştir. Buna rağmen bir çok poligami türü olan kuma evlilikleri gayriresmî olarak devam etmektedir. Özellikle Doğu ve Güneydoğu Anadolu Bölgesi'nde göreli olarak diğer bölgelere göre daha yaygın durumda olan poligami, resmî verilere göre Türkiye’de \% 2 civarındadır ve bu oranın büyük bölümünü kuma evlilikleri teşkil etmektedir. Nitekim poligaminin görülme sıklığı söz konusu bölgelerde \% 4.7-5 olarak tespit edilmektedir (Özkan ve diğerleri, 2006; Gücük ve diğerleri, 2010). Örneğin TBMM'nin Kadın Erkek Eşitliği Komisyonu'nun, evlilikle ilgili olarak 2013 yılında yayımladığı araştırmada Türkiye'de 372 bin kadının kuması olduğu saptanmıştır (TBMM, 2013).

\section{Türkiye'de Kuma Evliliklerinin Nedenleri}

Türkiye'de polijinin/kuma evliliklerinin ortaya çıkmasında ve yeniden üretilmesinde yukarıda sayılan genel faktörlerin yanı sıra söz konusu olguyu besleyen yöreye özel nedenler de görülmektedir.

Bunlardan birincisi ataerkil toplum yapısıdır. Sözü edilen yapı bir mekanizma olan evlilik kararlarının aileler tarafından alınmasına, kuma evliliklerinin toplumsal olarak yaygın ve meşru hale gelmesine yol açmaktadır.

İkinci neden eğitimdir. Hem erkeğin hem de konumuz olan kadınların eğitim seviyelerinin düşük olması sözü edilen evliliklerin olmasında çok etkilidir (Bal ve diğerleri, 2015:224).

Üçüncü neden, ailelerin çok fazla çocuğunun olması veya erkek çocuğa sahip olmamalarıdır. Ailelerin fazla çocuğa sahip olmasının yol açtığı ekonomik zorluklar kadınların bu 
sorundan evlenerek kaçmak isteğini beraberinde getirmektedir. Diğerinde ise çeşitli nedenlerle “erkek" evlat sahibi olmak arzusu erkekleri ikinci evlilik yapmak yönünde motive etmektedir. Şöyle ki genelde erkek çocuk sahibi olamayan erkekler biyolojik veya psikolojik "kusuru" kendinde değil kadında aramaktadırlar. Nitekim biyolojik açıdan kısır olan erkekler bunu ya bilmeden ya da "erkeklik adına" kendilerine kondurmadan ikinci, hatta daha fazla kadınla evlenebilmektedirler. Biyolojik bir sıkıntıları olmayan erkekler ise kendi aile içi yaşadığı toplumda statü kazanmak için daha fazla erkek çocuk istemektedirler.

Dördüncü neden sosyal çevre ve akrabalık ilişkileridir. "Hısım akraba" ilişkileri, çoğu zaman görücü usulüne dayanan kuma evliliklerine zemin hazırlamaktadır. Nitekim kuma evliliklerinin akrabalar arasında görülme oranı yüksektir. Bunda da akraba evliliklerinin yapılmasında etkili olan; akrabalık bağını güçlendirmek, "gelenek, görenek ve dinî inanışlar” gibi, yine "miras yoluyla toprağın bölünmesini önleyerek gelecek nesilleri güvence altına" almak gibi nedenler etkili olmaktadır (Tabak, 2008; 14).

Beşinci neden hane içi ekonomide ihtiyaç durulan "iş gücü”dür. Kadınların aileye sunduğu iş gücü arasında şunlar vardır: Ev işleri, erkeklerin yaptıkları işlere yardım amacıyla yapılan işler, aile fertlerine verilen duygusal hizmet, çocuk bakımı, hasta ve düşkün aile fertlerinin bakımı, kocalara sunulan cinsel hizmet ve çocuk doğurmak" (Acar-Savran, 2004: 49).

Altıncı neden, bu tür evliliklere meşruiyet kazandıran dinî ve geleneksel inanışlardır. Özellikle dinî nikâhla birlikte yaşanması ve toplumda buna izin verilmesi bu evliliklerde önemli olmaktadir.

Son neden olarak, evlenmekte geç kalan kadınların, "evde kalma” korkusundan mütevellit kuma evliliğini kabul etmeleri gösterilebilir.

\section{Araştırmanın Yöntemsel Modeli}

Bu çalışma, 2016-2017 yılında yapılmış bir alan araştırmasına dayanmaktadır ${ }^{1}$. Öncelikle şunu belirtmek gerekir ki Türkiye'de kuma evliliklerinin alana bulgularına dayanarak bilimsel olarak analiz edilmemesi ciddi bir eksikliktir. Bu çalışma işte böyle bir eksikliği gidermeye dönük bir adımdır.

Yapılan araştırmada niteliksel yöntem ve söz konusu yöntemde sıklıkla kullanılan derinlemesine görüşme tekniğgi kullanılmıştır. Nitel yöntem esas olarak "insan yaşantısına dair verilerden hareketle olayları belgeleme, insanların jest, mimik veya davranışlarını gözlemleye,

\footnotetext{
${ }^{1}$ Bu çalışma, Muğla Sıtkı Koçman Üniversitesi Bilimsel Araştırmalar Projesi (BAP) tarafından 16/123 numara ile desteklenen "Türkiye'de Toplumsal Bir Sorun Olarak Kuma Evliliği: Hatay Örneği” başlıklı projeye dayanmaktadır. BAP'a ve proje ekibine teşekkür ederiz.
} 
kaydedip belgelemeye ve analiz etmeye dayanır”. Buna görüşmecinin gözlem durumu eşlik eder (Neuman, 2006: 233). Nitel yöntemde görüşme, özellikle derinlemesine görüşme çok önemli bir yere sahiptir. Derinlemesine görüşme "insanların dünyaya bakış açılarını, deneyimlerini, duygularını ve algılarını ortaya çıkarmada kullanılan, güçlü bir yöntem şeklidir” (Yıldırım ve Şimşek, 2018: 42).

Araştırmanın alanı olarak söz konusu evliliklerin görüldüğü Hatay ili ve Samandağ ilçesi seçilmiştir. Adı geçen yerde yaşayan hem ilk evlenen eşlerle hem de kumalarla yüz yüze derinlemesine görüşmeler yapılmıştır. Bu araştırma toplamda 16 resmî nikâhlı ilk/eş ve 16 kuma kadınla görüşme gerçekleştirilmiştir. Yapılan görüşmelerde tekrar cevaplar gelmeye başlayınca nitel araştırmada benimsenen "doyum noktası” ilkesi gereği görüşmeler sonuçlandırılmıştır. Görüşme yapılan kadınlara kartopu örneklemi ile ulaşılmıştır. Araştırma yaparken kuma evliliği yapan kadınlara ulaşmak ilk etapta zor olsa da, bu evliliği yapmış olanların yönlendirmeleri bu zorluğu gidermede önemli ölçüde yararlı olmuştur. Özellikle böylesi hassas bir konuda katılımcılara güven telakki etmek adına görüşmelere "tanıdık” birileri ile gidilmiştir.

Görüşme soruları iki farklı formatta hazırlanarak hem resmî nikâhlı kadınlara hem de kuma olarak evlenen kadınlara farklı mekânlarda ayrı ayrı yöneltilmiştir. Ortalama 45 dakika süren görüşmeler sohbet havasında geçmiş olup kişilerin kendilerini rahat ifade edecekleri alanlar oluşturulmuştur. Mülakatlar ses kaydı ile yapılarak tüm konuşmalar incelenmiş aynı zamanda tüm detaylarına bakılmıştır. Ses kaydı alınırken görüşülen kişilerin bazılarının Türkçe bilmemeleri ve Arapçaya hâkim olmaları nedeniyle ilgili kişilerle Arapça konuşulmuştur. Arapçanın yetmediği veya eski dil ile ilgili tabirlerin anlaşılamadığı bazı durumlarda araştırmacıların yakınları devreye girmiştir. Katılımcıların kimlik bilgileri etik kurallar gereği verilmemiş onlara $\mathrm{K} 1, \mathrm{~K} 2$ şeklinde kodlar verilmiştir.

Araştırmada toplanan verilerin “orijinal yapısına mümkün oldukça bağlı kalarak ve gerektiğinde araştırma örneklemini oluşturan bireylerin söylediklerini doğrudan alıntı yaparak okuyucuya betimsel bir yaklaşımla veriler” sunulmuştur (Yıldırım ve Şimşek, 2018: 237). Verilerin sınıflandırılması analizinde araştırma problematiğini tanımlayan sorular belli temalar altında tablolar haline getirilmiştir. Söz konusu temalar demografik ve problematik analiz altında şu şekilde sınıflandırılmıştır:

- Ekonomik problemler kuma evliliklerini nasil etkilemektedir?

- Erkek çocuk sahibi olmak bu evliliklerde nasıl bir rol oynamaktadır?

- Ataerkil yapının bu evliliklerde rolü nasıldır?

- Sosyal çevre kuma evliliklerinde nasıl etkiler bırakmaktadır? 


\section{Verilerin Analizi}

Kuma evliliklerinin teorik bölümde tartışıldığı üzere birçok nedeninin olduğu varsayılabilir. Kuma evliliğinin nedenlerinin ne olduğu şeklindeki soruya katılımcıların verdikleri cevaplar söz konusu evliliklerin adeta özeti niteliğindedir.

Tablo 1. Kuma Evliliğinin Nedenleri

\begin{tabular}{|l|l|}
\hline K. 1 & İstedim. Aynı evde yaşamıorlar o yüzden kabul ettim. Kader kısmet ya. \\
\hline K. 3 & Ben çocukları olmadığ için evlendim. \\
\hline K. 4 & Sevdiğim için kabul ettim kuma evliliğini. \\
\hline K. 5 & Evet çocuk için evlendim. \\
\hline K. 6 & Valla yemin etmiştim hatta ben de yeminliydim ki istemem. \\
\hline K. 7 & Ben daha önce başkasına nişanlıydım istemedim ve onunla evlendim. \\
\hline K. 9 & Sevdiğim için. \\
\hline K. 16 & $\begin{array}{l}\text { Maddi durum yüzünden biz altı kardeştik durumumuz bayağı kötüydü. Fakirlik çekiyorduk } \\
\text { yoksulduk. Bu yüzden evlendim. }\end{array}$ \\
\hline
\end{tabular}

Katılımcılar kuma evliliklerinin nedenlerine dair olarak şunları sıralamaktadırlar: Sevgi ihtiyacı, erkeğin ikna edişi, maddi durum yetersizliğine karşın çok kardeşli olmak, erkek çocuk istemek. Şimdi söz konusu nedenleri detaylı şekilde analiz edelim.

\section{Demografik Analiz}

Tablo 2. Kuma Olarak Evlenen Kadınların Yaş ve Eğitim Durumları

\begin{tabular}{|c|c|c|c|}
\hline K.1 & 46 & K.1 & Okumadım. \\
\hline K. 2 & - & K.2 & Yok valla gitmedim. \\
\hline K. 3 & 60 olmadım daha. & K.3 & $\begin{array}{l}\text { Gece okuluna gittim ben } 40 \text { 'l } 1 \text { yaşlarda ama } \\
\text { ben çok gitmedim. }\end{array}$ \\
\hline K. 4 & 47 yaşındayım daha. & K.4 & Yok okumadım, göndermediler. \\
\hline K. 5 & 1968 doğumluyum. & K.5 & Yok okumadım. \\
\hline K. 6 & $\begin{array}{l}\text { Valla ne diyim bilmiyorum. } 60 \text { küsür } \\
\text { falan. }\end{array}$ & K.6 & Yok valla hiç okumadım. \\
\hline K. 7 & 53 yaşındayım. & K.7 & Yok okumadım. \\
\hline K. 8 & $\begin{array}{l}\text { Yaşım 60'larda ama } 65 \text { değil yoksa } \\
\text { yaşl11ık maaşı alırdım. }\end{array}$ & K.8 & Gittim ama adımı yazmayı bilmiyorum. \\
\hline K. 9 & 53'e geçtim. & K.9 & İlkokulu bitirdim. \\
\hline K. 10 & 63 yaşındayım. & K.10 & Yok okumadım. \\
\hline K. 11 & 1960 doğumluyum. 56 yaşındayım. & K.11 & İlkokul mezunuyum. \\
\hline K. 12 & $\begin{array}{l}\begin{array}{l}\text { Bilmiyorum kaç olduğumu } \\
\text { arasında biliyorum. }\end{array} \\
\end{array}$ & K.12 & Hayır gitmedim. \\
\hline K. 13 & Yaşım 59. & K.13 & $\begin{array}{l}\text { Hayır gitmedim burada iki aylığına gittim } \\
\text { sadece. }\end{array}$ \\
\hline K. 14 & 30 yaşındayım. & K.14 & Yok gitmedim. \\
\hline K. 15 & & K.15 & \\
\hline K. 16 & 38 yaşındayım. & K.16 & Açık öğretimden liseyi bitirdim. \\
\hline
\end{tabular}

Kuma evliliği yapan kadınların yaşları 30 ve 80 aralığındadır. Kuma olarak evlenen kadınların eğitim durumuna bakıldığında genellikle düşük bir eğitim seviyesine sahip olduğu 
görülmektedir. Katılımcılardan K.9 ve K.11 ilköğretimi, sadece K.16 liseyi bitirmiştir. Geri kalan kadınlar genel olarak eğitim almamıştır. Söz konusu faktör kuma evliliklerinin hem nedeni hem de sonucudur. Kadınların sahip oldukları düşük eğitim seviyesi kadınlar için ciddi bir sorun olmaktadır. Çünkü kadınların bilgi düzeyleri, yaşadıkları karşısında nasıl davranmaları veya yaşamlarını nasıl anlamlandırmaları gerektiği noktasında oldukça etkili olmaktadır. Düşük eğitimli kadın her şeyden önce bu dünyaya dair bilgi edinmede dezavantajlı konuma itilmektedir. İkinci olarak alternatif bir dünya tasarımından uzak kalarak mevcut geleneksel yaşantının dışına çıkamamakta, bu nedenle de söz konusu yaşantıyı zihninde normalleştirmektedir. Böylece kuma evliliklerinin birazdan değineceğimiz nedenlerine karşı savunmasız kalmaktadırlar. Pratikte ise bazı kadınlar okuryazar olmadığı için iş bulamamaktadırlar.

Burada K.4.'ün beyanında yer alan “göndermediler” ifadesi diğer kadınlar tarafından dile getirilmemiş olsa da saha notlarından edindiğimiz izlenim, "kadının okumaya ihtiyacı yoktur" şeklindeki algının önemli olduğu yönündedir. Bu sonuçlar White ve Burton’un (1988) kadınların düşük eğitimli olmalarının polijininin ortaya çıkmasında ve yeniden üretiminde etkili olduğu şeklindeki görüşlerini desteklemektedir.

Tablo 3. Kumaların Sahip Oldukları Kardeş Sayısı

\begin{tabular}{|l|l|}
\hline K. 1 & 4 oğlan 3 kızdık. \\
\hline K. 2 & Bir erkek beş kız. \\
\hline K. 5 & 7 kardeşiz. \\
\hline K. 6 & Biz 2 erkek 4 kız. \\
\hline K. 8 & Biz 4 erkek 5 kı biri de öldü. \\
\hline K. 9 & Biz 5 kız 3 erkek var. \\
\hline K. 10 & Biz 7 kardeştik. 3 erkek 4 kız olmak üzere. \\
\hline K. 11 & 4 kardeşiz bir kardeşim vefat etti üç kardeş kaldık. \\
\hline K. 12 & 7 kardeşiz 3 kız 4 erkek. \\
\hline K. 13 & 7 kardeşiz. \\
\hline K. 14 & 3 kız 2 erkek 5 kardeş. \\
\hline K. 16 & 6 kardeşiz. \\
\hline
\end{tabular}

Katılımcıların ifadelerinden de anlaşılacağı üzere kuma olarak evlenen kadınlar Türkiye ortalamasının oldukça üstünde kardeşe sahiptirler (6 kardeş ve üzeri). Bu durum gelir durumu düşük ve çok fazla çocuğa sahip olan ailelerin kız çocuklarını erken yaşta evlendirmeleri ile sonuçlanabilmektedir. Çünkü bu evlilikleri "sofradan bir boğazın eksilmesi” gibi ekonomik olarak nispeten rahatlamak ve evin nüfusunu azaltmak olarak değerlendirebilmektedirler (Şen, 2014). Aynı neden kuma evlilikleri için de geçerlidir. Yoksulluk ve aile için kalabalık nüfus, kadınlar açısından bir an önce evlenmek adına bir tür "rasyonel seçim" olarak da görülebilmektedir. Kadınlar evlenmeden önceki pek de iç açıcı olmayan ekonomik durumlarından kurtulmak için 
"kuma” olarak evlenmeyi bir tür kurtuluş olarak görebilmektedir. Çünkü hane içinde çok kardeşli olmak, kadına "boş yatırım” gözüyle bakıldığından yukarıda ifade edildiği şekliyle eğitim gibi herhangi bir fırsatın verilmediği ataerkil toplumlarda, bu tür evlilik kadına bir tür seçenek gibi görünebilmektedir. Nitekim önceki bölümde teorik bölümde ele alındığı üzere Murdock (1964), polijininin ortaya çıkmasında ve yeniden üretilmesinde özellikle "kadınların erkeklere göre ekonomik ve sosyal olarak daha düşük seviyede olduğu ataerkil yaşamın daha uygun olduğunu" ifade etmiştir. Kısacası sosyolojik koşullar bu durumlarda olduğu üzere bazen kişisel seçimmiş gibi görülebilmektedir.

Tablo 4. Katılımcıların Evlilik Yaşları

\begin{tabular}{|c|c|c|c|}
\hline & İlk Eş & & Kuma Olarak Evlenen Kadın \\
\hline K.1 & $\begin{array}{l}\text { Ne } 18 \text { 'i... hatta oğlum okula gittiğinde } \\
\text { daha resmî nikâhım yoktu. }\end{array}$ & K. 1 & 22 yaşında evlendim. \\
\hline \multirow[t]{3}{*}{ K. 2} & $\begin{array}{l}\text { Valla tam bilmiyordum. } 13- \\
14 \text { yaşlarındaydım. }\end{array}$ & K. 2 & 17 yaşında evlendim. \\
\hline & & K. 3 & Ben 22 yaşında evlendim. \\
\hline & - & K. 4 & 37 yaşında evlendim. \\
\hline K. 5 & 16 yaşında evlendim. & K. 5 & Valla bilmiyorum 2327 yaşlarında evlendim. \\
\hline \multirow[t]{2}{*}{ K. 6} & Ben yaklaşık 13 yaşında evlendim. & K. 6 & Galiba 20 ya da 30 yaşlarında \\
\hline & - & K. 7 & Ben daha küçüktüm evlendiğimde. \\
\hline K. 8 & Küçük yaşta evlendim. & K. 8 & $\begin{array}{l}\text { Valla bilmiyorum tarlayı üzerime } \\
\text { yapacaklardı ama yapamamışlardı. }\end{array}$ \\
\hline K. 9 & Resmî nikâh düşmemişti. & K. 9 & 20 yaşındayken evlendim. \\
\hline K. 11 & 20 yaşından önce evlendim. & K. 13 & 18 yaşında evlendim. \\
\hline K. 14 & 17 yaşında evlendim. & K. 14 & 23 yaşındaydım. \\
\hline K. 16 & 20 yaşında evlendim. & K. 16 & 28 yaşında evlendim. \\
\hline
\end{tabular}

Kuma olarak giden kadınların evlenme yaşı bir katılımcı hariç 18 yaş üstüdür. Türkiye İstatistik Kurumunun 2019 verilerinde dahi Türkiye'de kadınların evlenme yaşının olan ortalama 25 yaşın üstünde olduğu görülmektedir (www.tuik.gov.tr, Erişim tarihi 13.07.2020). Fakat kadınların 30-40 yıl önce evlendikleri düşünüldüğünde bu yıllar 1990'lara karşılık gelmekte ve o y1llarda bölgedeki evlilik yaşının ortalama 22 olduğu düşünüldüğünde, kumaların evlenme yaşları Türkiye ortalamasının üstündedir.

$\mathrm{Bu}$ tür durumların analizinde çapraz okuma ve analiz yapmak son derece önemlidir. Bu oran kadınların kuma olarak gittiği yerde ilk eşleri olan kadınların evlenme yaşlarının oldukça üstündedir. Nitekim ilk eş olan 9 kadın, çocuk denebilecek yaşta evlenirken görüşülen 12 kuma kadının daha geç yaşta evlendiği gözlenmektedir. Aynı sosyal çevrede bir kadın erken diğeri geç olarak evleniyorsa değişen nokta sosyolojik koşullarda değil bireysel durumlardadır. Nitekim aynı koşullar altında kuma olarak evlenen kadınları bu evliliğe iten nedenlerden birisinin geç evlenme veya evlenememe korkusundan, sosyal bağlamı ile ifade edildiğinde "evde kalma korkusundan" 
kaynaklandığı düşünülebilir. $\mathrm{Bu}$ durum ataerkil toplumlarda kadın üzerinde oluşan kültürel baskılardan hatta kâbuslardan biridir. Geç olgunlaşmayı ifade etmesi bakımından kullanılan Anadolu halk tabiri ile "kış armudu” olma, yani geç evlenme korkusu, kadınların kumalığg kabul etmesinde etkili bir faktör olarak rol oynamaktadır. Bu noktada kadınlar içinde bulundukları durumun onlara yükledikleri "sosyal mahcubiyet" halinden kurtulmak için tercih dışı da olsa kuma evliliklerine yönelebilmektedirler. İşte bu nokta Stanley Witkowki, Melvin ve Carol Ember'in, erkeklerin geç evliliği ile polijini arasında kurdukları ilişkiyi, bu çalışma çerçevesinde geç evlenen kadınlar ve polijini arasında kurmak yerinde olacaktır. Çünkü literatürde bu teze rastlanmamıştır. Tabii ki bu tezin çeşitli boyutlarda ve geniş ölçekte test edilmesi gerekmektedir. Fakat bu çalışmada analiz edildiği şekliyle, Türkiye'de kadınların genel sosyal kabul ölçütlerine göre evlenmek konusunda "geç kalmaları", kumalığa razı gelmelerinde etkili olmaktadır. Bu faktör polijini konusunda Türkiye’ye özgü bir neden olarak görülmelidir.

Tablo 5. Katılımcıların Sahip Oldukları Çocuk Sayısı

\begin{tabular}{|c|c|c|c|}
\hline \multicolumn{2}{|c|}{ İlk Eş } & \multicolumn{2}{|c|}{ Kuma Olarak Evlenen Kadın } \\
\hline K. 1 & $\begin{array}{l}8 \text { sağ ölenlerle beraber on dört çocuk } \\
\text { doğurdum. }\end{array}$ & K.1 & 3 kız 2 erkek olmak üzere 5 çocuğum var. \\
\hline K. 2 & 6 çocuğum var. & K.2 & $\begin{array}{l}\text { Eski eşimden } 1 \text { kız bir erkek. Bundan da } 2 \\
\text { erkek var. }\end{array}$ \\
\hline K. 4 & 5 çocuğum var & K.3 & Beş kız dört erkek çocuğum oldu. \\
\hline K. 6 & Sadece 3 erkek oğlum var. 2 tane öldü. & K.5 & Yok. \\
\hline K. 7 & 4 çocuğum var. & K.6 & Yok valla çocuklarım yok. \\
\hline K. 8 & 6 erkek 2 kızım var. & K.8 & Benim 5 erkek 6 kızım var. \\
\hline K. 9 & $\begin{array}{l}\text { Benim iki kızım var. Ama kumamdan da } \\
\text { çocuklarım var. }\end{array}$ & K.10 & Çok şükür 3 erkek 2 kız çocuğum var. \\
\hline K. 11 & 3 çocuğum var. & K.11 & $\begin{array}{l}10 \text { tane çocuğum var. } 9 \text { Çocuğum bu } \\
\text { kocamdan diğer çocuğum ölen kocamdan. }\end{array}$ \\
\hline K. 12 & 2 kızım var. & & \\
\hline K. 13 & Benim 5 tane çocuğum var. & K.13 & 5 tane çocuğum var. \\
\hline K. 14 & Hayır olmadi. & K.14 & Evet sadece buradakiler 2 erkek 1 kız. \\
\hline K. 16 & Yok. & K.16 & İki çocuğum var. \\
\hline
\end{tabular}

Görüşülen kadınların ortalama 4 ila 8 arasında çocukları vardır. Kuma evliliklerinin gerisinde yatan nedenlerden birisinin geleneksel olarak hem erkeğin hem de kadının erkek çocuk sahip olmak isteğinin olduğu genelde kabul gören bir tezdir. Erkek çocuk sahibi olmak istemenin de çok çeşitli gerekçeleri vardır. En önemli gerekçelerden birisi, “erkek” soyunun devam ettirilmek istenmesidir. Bunun yanı sıra mülkiyetin devamını sağlamak da önemli gerekçelerden bir diğeridir. Fakat özellikle geleneksel toplumlarda erkek çocuk sahibi olmak ifade edilen nedenlerden dolayı sadece erkek tarafından değil kadın tarafından da sevinçle karşılanan bir durumdur. Sözü edilen toplumlarda yaygın biçimde görülen, “erkek adamın erkek çocuğu olur” düşüncesi her ne kadar 
erkekler için bir statü ve saygınlık kaynağı olsa da erkek evlat doğuran kadınların da bu statüden pay aldıkları görülmektedir. Konumuz olan kuma evliliklerine yol açan nedenlerden biri olarak, ilk eşin erkek çocuk doğuramamasından mütevellit "kusurluluk" imajı/hali ve dolayısıyla erkeğin bu nedenle ikinci bir kadınla evlenme gerekçesini oluşturan neden, yaptığımız araştırmada kendiliğinden bir faktör olamamaktadır. Nitekim ilk eşlerin yarısından fazlası erkek çocuk doğurmuşlardır. Bu anlamda erkek doğuramayan kadınlara yönelik olarak yakıştırılan "eksik kadın" tanımı bu çalışmada karşılık bulmamaktadır. Yine erkek çocuk doğuramayan kadınlara özellikle kayınvalideleri tarafından yöneltilen, "erkek doğurmaz isen oğlumu başkasıyla evlendiririm” şeklindeki geleneksel tehdidin eski gücünde olmadığı görülmektedir.

\section{Problematik Analiz}

\section{Hane İçi Emek-ücretsiz emek}

Tablo 6. Ev İşlerinin Yapılma Durumu

\begin{tabular}{|l|l|}
\hline K. 2 & Evet herkes kendi işini yapar. \\
\hline K. 3 & Her şeyi beraber yapıyoruz. \\
\hline K. 4 & Herkes aynı yerde yapıyordu ama beraber yemiyorduk. \\
\hline K. 5 & Hiçbir şey fark etmiyor. \\
\hline K. 6 & Her zaman ben yaptım yapmaya da devam ediyorum çok şükür. \\
\hline K. 7 & Ben yaparım her şeyi. \\
\hline K. 8 & Evet, beraber yapardık. \\
\hline K. 14 & Beraber yaparız. \\
\hline K. 16 & Beraber yapıyoruz. \\
\hline
\end{tabular}

Evde yemekleri ve ev işlerini kim yapar? sorusuna verilen cevaplardan da anlaşılacağı üzere gerek ilk eşler gerekse kumalar ev işlerini yapmak konusunda kısmi bir uzlaşma sağlamışlardır. Ataerkil toplumlarda kadının ev işlerini yapması onların asli görevi olarak görülmektedir. Kadın evlenmeden önce ailesinin evinde, evlendikten sonra kocasının evinde ev işlerini yapmak zorundadır. Resmî nikâhlı ilk eş olmak ya da kuma olmak bu iş bölümünü değiştirmemekte, ilk eş veya kuma olmak kendilerine herhangi bir avantaj sağlamamaktadır. Kadınların çalışması sadece ev işleriyle sınırlı kalmamaktadır. Aşağıdaki tabloda da görüleceği üzere kadınlar ücretsiz emek içeren işlerde çalışmaktadırlar. 
Tablo 7. Kadınların Çalışma Durumları

\begin{tabular}{|c|c|c|c|}
\hline \multicolumn{2}{|l|}{ İlk Eş } & \multicolumn{2}{|c|}{ Kuma Olarak Evlenen Kadın } \\
\hline K. 1 & $\begin{array}{l}\text { Tarla yok maaş da almıorum. } \\
\text { Çalışmıyorum sadece bir tane ineğim var } \\
\text { ama getirisi yok. }\end{array}$ & K.1 & $\begin{array}{l}\text { Tabii ki çalışıyorum. Önceden de çalıştım } \\
\text { şimdi de çalışıyorum. Tarlada çalışıorum } \\
\text { inek bakıyorum. }\end{array}$ \\
\hline K. 2 & $\begin{array}{l}\text { Tabii ki çalışıyorum. Her yerde } \\
\text { çalışıyorum. Pamuğa bel vurduk. Şimdi } \\
\text { de gündeliğg falan gidiyoruz. Tarlada } \\
\text { ekin ekiyorsak o kadar. }\end{array}$ & K.2 & $\begin{array}{l}\text { Valla var. Eskiden çalışıyorduk ama } \\
\text { çalışmıyorum artık. }\end{array}$ \\
\hline K. 3 & Yok, bir yerde çalışmıyorum. & K.3 & $\begin{array}{l}\text { Yok bizde iş yok ki. Ama daha önce tabii ki } \\
\text { gidiyordum }\end{array}$ \\
\hline K. 4 & $\begin{array}{l}\text { Allah'a şükür çalışıyorum tabii hem de } \\
\text { gündelikte bir yerden bir yere } \\
\text { sürükleniyorum. }\end{array}$ & K.4 & Ailemde çalışıyordum ama bu kadar değil. \\
\hline K. 5 & $\begin{array}{l}\text { Benim gelirim yok daha önce yevmiyeye } \\
\text { gidiyordum arada sırada yani denk } \\
\text { geldikçe. }\end{array}$ & K.5 & Yok çalışmıyorum. \\
\hline K. 6 & $\begin{array}{l}\text { Tabii ki çalışıyorum ev işleri, tarla, inek } \\
\text { bakımı bunlar bizim işlerimizdi. }\end{array}$ & K.6 & Eskiden Mersin'e kadar giderdim. \\
\hline K. 7 & $\begin{array}{l}\text { Ben çocuğum olana kadar çalıştım sonra } \\
\text { bıraktım. Ama o kadın gelene (...) onu } \\
\text { yetişene kadar öyle oldu. Sonra ben } \\
\text { çocuklarıma bakmak için tekrar } \\
\text { çalışmaya başladım. }\end{array}$ & K.8 & Sonra biz beraber çalıştık. \\
\hline K. 8 & $\begin{array}{l}\text { Tabii ki pamuğa gittik Söke’ye gittik } \\
\text { tarlada çalıştık. Kış gelirdi sebze ekerdik. }\end{array}$ & K.9 & $\begin{array}{l}\text { (Çalışmak anlamında) Hem kendi ailemde } \\
\text { hem de burada yaşadım. }\end{array}$ \\
\hline K. 9 & Tabii ki çalışıyorum kim bakacak yoksa. & K.10 & $\begin{array}{l}\text { Bekârken çalışıyordum ama evlendikten } \\
\text { sonra yok. }\end{array}$ \\
\hline K. 11 & $\begin{array}{l}\text { Evet, çalışıyorum fakirim gündelikçi } \\
\text { olarak çalışıyorum }\end{array}$ & K.11 & Hayır çalışmıyorum. \\
\hline K. 13 & $\begin{array}{l}\text { Çok çalıştım mandalina toplama işinde } \\
\text { çalışım. }\end{array}$ & K.12 & Evet, oldum bahçe işlerinde çok çalıştım. \\
\hline K. 14 & Yok, çalışmadım. & K.13 & Evet. \\
\hline K. 16 & 500 TL gelirim var. & K.14 & Yok çalışmadım. \\
\hline
\end{tabular}

Düzenli bir gelirlerinin olmadığı anlaşılan kadınlar, mevsimsel/kısa dönemli olduğu yerlerde kısmi olarak ücretli ama çoğu zaman da ücretsiz emek karş1lığ1 çalışmaktadırlar. Görüşülen kadınların gerek evlenmeden önce gerekse evlendikten sonra ev işleri, bahçe, tarla ve hayvan bakımı olmak üzere, Acar ve Savran'ın ev içi emek bağlamında belirttikleri çeşitli işlerde çalıştıkları görülmektedir. Görüşmelerin yapıldığı an (çeşitli nedenlerle) çalışmayan kadınların önceleri çalıştıkları, bazılarının ise bekâr iken çalıştıkları fakat çalışmanın başladığı esnada çalışmadıkları görülmüştür. Burada üzerinde durulması gereken noktalardan birisi kadınların evlenmeden önce de evlendikten sonra da hane içi işlerde çalışmaya devam etmeleridir. Elde edilen veriler, Grossbar'ın teorik bölümde tartışıldığg üzere polijini evliliklerde erkeğin genel olarak ücretsiz kadın emeğinden ve özellikle aile işçiliği üzerinden ücretsiz olarak yararlandığı şeklindeki teziyle paralellik göstermekte, buna karşın kadının ücretli emeğinden yararlanamadığı şeklindeki teziyle de çelişmektedir. 
İlk eşlerin veya kumaların çalışmaları başka bir bakımdan kadın emeğinden yararlanılması hatta sömürülmesi olarak da görülebilir. Çünkü özellikle ev içi işlerde çalışırken emeklerinin ücret karşılığı olmadığından bunun bir tür zorunluluk olarak doğallaştırıldığı bir ortam kadınların aleyhine olmaktadır. Çünkü Türkiye'de gayriresmî olan kuma evlilikler, örneğin kadınların miras yoluyla veya bir boşanma dururumda mülkiyetten paylarını alamamalarına yol açmaktadır. Bu da kumaların gerek kendilerine gerekse çocuklarına bir gelecek sağlamak amacıyla sürekli olarak çalışmak zorunda kalmaları demektir. Bu noktada K.9'un "Tabii ki çalışıyorum kim bakacak yoksa" sözü durumu anlatmak adına çok önemlidir. Diğer yandan çalışan kadınların çalıştığı yerlere çocuklarını da götürdükleri göz önüne alındığında, ev içi emeğe küçük çocukların da katıldığı hemen görülecektir. İște burası, unutulan veya çalışılması ihmal edilen bir nokta olarak çocukların da ücretsiz iş gücü veya (gizli) çocuk işçiliğini gündeme getirmek bakımından kuma evliliklerinin diğer bir boyutunu teşkil etmektedir.

Tablo 8. Katılımcıların Kumalık Olgusunun Bölgede Yaygınlık Durumuna Dair Görüşleri

\begin{tabular}{|c|c|c|c|}
\hline \multicolumn{2}{|c|}{ İlk Eş } & \multicolumn{2}{|c|}{ Kuma Olarak Evlenen Kadın } \\
\hline K. 3 & $\begin{array}{l}\text { Tabii ki var. (nerede olduğundan } \\
\text { bahsediyor kumalar için). }\end{array}$ & K. 2 & Evet burada çok var. \\
\hline K. 4 & Tabii çok var burada. & & \\
\hline K. 5 & $\begin{array}{l}\text { Valla bilmiyorum burada çok var mesela } \\
\text { Koyunoğlu'nda yoktur. Ama burada var. } \\
\text { Eğer eşi falan öldüyse anca o zaman } \\
\text { evlenirler. Ya da boşandiysa. }\end{array}$ & K. 5 & $\begin{array}{l}\text { Bence iyi değil tabi ama çok yaygın değil. } \\
\text { (araya kuma girerek yaygın her } 5 \text { evden } \\
\text { birinde bu tür evlilikler yaşanıyor diyor). } \\
\text { Yok yaygın değil diyor. }\end{array}$ \\
\hline K. 6 & Burada çok fazla özellikle bu ailede. & & \\
\hline K. 8 & \begin{tabular}{|l|} 
Evet var. Herkes birbiriyle tanıdık ne \\
desinler ki.
\end{tabular} & K. 8 & Tabii ki yaygın yani (burada örnek veriyor.) \\
\hline K. 11 & $\begin{array}{l}\text { Var tabii. Yok mu? Çevremde iki kişi var } \\
\text { ikişer kuma getirmişler. }\end{array}$ & & \\
\hline K. 14 & Yok, yaygın değil. & K. 14 & $\begin{array}{l}\text { Evet, var bazıları da ortada neden yokken } \\
\text { bile bu tür evlilikler yaparlar. Benim nenem } \\
\text { Türkmen bizim oralarda normal } \\
\text { karsılanıyor. }\end{array}$ \\
\hline
\end{tabular}

“Etrafınızda kumalık olgusu yaygın mıdır?” şeklindeki soruya katılımcılar yaşadıkları yer ve ortama göre soruya farklı cevaplar vermektedirler. Çünkü bölgesel olarak bu olgunun sıklıkla görüldüğü veya görülmediği yerlerin bilgisine sahip kadınlar genelde kuma evliliklerinin yaygın olduğunu düşünmektedirler. Katılımcıların beyanları incelendiğinde "çevrede" birçok kişi tarafından yapılıyor olması bu tür evliliklerin adeta meşru gerekçesini oluşturmaktadır. Kültürel kıskaç olarak tanımlanabilecek bu durum, doğru olmayan fakat normalleşen sosyal eylemlerin insan davranışlarında belirleyici bir etkide bulunmasına bir örnek olabilmektedir. Yani yaygınlık/sıklık durumu bir olgunun, sosyal genelliğe uyum esnasında "normal" nedenine dönüşebilmekte, ortaya çıkan sonuç nedenin kendisi olabilmektedir. Nitekim sosyal çevrede 
görülen her olgu normal kapsamına alınmakta, algılarda meşrulaştırılıp yeniden üretilebilmektedir. Burada direnilmesine isteksiz hatta imkânsız kurumsal yapıların ve kolaylaştırıcı sosyal etmenlerin, insanların davranışlarına yön vermesi kuma evliliklerde rahatlıkla gözlenmektedir. Nitekim toplumun kumalığa bakışına dair bizatihi kumaların görüşlerini içeren aşağıdaki tablo bu analizi teyit etmektedir.

Tablo 9. Toplumun Kumalara/Kumalığa Bakışı

\begin{tabular}{|l|l|}
\hline K. 1 & Normal karşıladılar. Kabullendiler. Herkes öyle evlendiği için normal. \\
\hline K. 2 & İnceden tabii ki konuşuldu sonra alışıldı. \\
\hline K. 3 & Acaba çocukları olacak mı olmayacak mı insanlar buna baktı. \\
\hline K. 4 & Buraya gelince mi/kocamın köyüne geldikten sonra mı? \\
\hline K. 5 & $\begin{array}{l}\text { Derler bazı kişiler herkes konuşabilir zoruma gidiyor bazen bazıları zevkle evleniyor bazıları da mazeretle } \\
\text { evleniyor. }\end{array}$ \\
\hline K. 7 & Ben memnunum hayatımdan. \\
\hline K. 9 & Ne desinler ki nasıl geldi arkasında diyorlar. \\
\hline K. 10 & $\begin{array}{l}\text { Valla bazı yerler için laf taşırdı bazı yerlerde de konuşurlardı. Amcam ve kayın annem çok çektirdiler. } \\
\text { Herkes bilir yani. }\end{array}$ \\
\hline K. 16 & Bazen kötü bazen iyi değişiyor. \\
\hline
\end{tabular}

Toplum nezdinde kabul edilen, normalleştirilen kumalık olgusu, "Ne desinler ki nasıl geldi arkasında diyorlar” ifadelerinde de görüleceği üzere bir gelenek olarak takip edilmektedir. "El âlem", "hısım-akraba", "eş-dost” şeklinde görülen sosyal iradeler, insan iradesini yer yer etkileyen, belirleyen ve yönlendiren yer yer zorlayan gölge kurumlar olarak iş görmektedirler. Dolayısıyla ataerkil yapının sert nesnel koşulları altında kalan kadınların türlü kültürel gerekçelere maruz kalmasıyla oluşan "koşullandırılmış rıza", bir tür kişisel tercih olarak görülebilmektedir (Şen, 2014). Başka bir deyişle bireysel tercihmiş gibi görülen davranışların gerisinde, sosyal alanda inşa edilen "laf taşımak", "dedikodu” gibi yönlendirici, teşvik edici sosyal pekiştireçlerin rol oynadığ kurumsal realiteler yatmaktadır. Bir olgu gelenek halini aldıktan sonra sorgulanmaktan ziyade uygulanması beklenen toplumsal eyleme dönüşmektedir. Bu da kısmi veya açıktan kurumsal zorlanmalar devreye girebilmektedir. Așağıdaki tabloda bu iddiayı destekleyen ifadelere rastlanmaktadır. 
Tablo 10. Katılımcıların Evliliği İsteme, İknâ veya Zorlama Durumu

\begin{tabular}{|l|l|}
\hline K. 1 & Yok kimse zorlamadı kendi isteğimle canım. \\
\hline K. 2 & $\begin{array}{l}\text { Annem bana dedi ki gel çocuklarınla beraber ben sana bakacağım dedi iki üç ay kaldım sonra } \\
\text { geri dönmek zorunda kaldım. }\end{array}$ \\
\hline K. 3 & Yok ailem 1srar etmedi. \\
\hline K. 4 & $\begin{array}{l}\text { Tabii ki o zorladı. Nasıl biliyor musun ben başkasıyla evlenecektim ama o dedi ki benimle } \\
\text { evleneceksin ve evlendik. }\end{array}$ \\
\hline K. 5 & Tabii ki ikna ettiler. \\
\hline K. 6 & Yok aslında... Kimse kimseyi zorlamadı diyorum ya yeminliydim. \\
\hline K.7. & Valla kandırdı ikna etti seni seviyorum dedi bir şeyler dedi öyle geldik. \\
\hline K. 8 & Zorla aldı beni yani. \\
\hline K.9 & Biz sevdik birbirimizi geldik. \\
\hline K. 10 & Kimse zorlamadı. \\
\hline K. 11 & $\begin{array}{l}\text { Ben kendi isteğimle evlendim başka çarem yoktu ama insanların dedikodusu ve konuşmaları } \\
\text { bizim buralarda genel olarak kadınlar hakkında konuşulur bu yüzdende evlenmeyi tercih ettim. }\end{array}$ \\
\hline K. 16 & Yok, zorlamadı kendi isteğimle evlendim. \\
\hline
\end{tabular}

Tabloya bakıldığında kadınların bir kısmının genel olarak evliliğe zorlanmadıkları aksine kendi rızalarıyla, diğer bir kısmının ise dolaylı veya doğrudan baskı altında kalarak evlendikleri görülmektedir. Kendi rızasıyla karar verenlerin ilk etapta herhangi bir baskı altında kalmadıkları belirtilse de, bu kararlarını yönlendiren birçok kişisel ve sosyal faktör hemen kendini hissettirmektedir. Bunlardan ilki aile baskısıdır. Nitekim belli bir yaşa gelip evlenmeyen kadınların, aile içinde yenge, anne, baba baskısı bu evliliklerin yaşanmasında etkili olmaktadır. Kadınlar bu noktada baba evinde 'sığıntı' olarak kalmaktansa kuma olmayı kabul etmektedirler. Diğer yandan K.11'in bu durumun kendi üzerinde yarattığı çaresizlik duygusu bahsedilen sosyal baskının en etkili olanlarından biridir. Çünkü dul bir kadının tek başına yaşamasının ne denli zor olduğu düşünüldüğünde bu durum daha da iyi anlaşılmaktadır. Mevcut toplumsal koşullarda boşanmış bir kadının tek başına yaşamasının ne denli zor olduğu düşünüldüğünde bu durum daha da iyi anlaşılmaktadır. Diğer bir zorluk ise bu evlilikte mutsuz olmasına karşın geri dönülememesidir. Örneğin, K.2’nin “Annem bana dedi ki ‘gel çocuklarınla beraber ben sana bakacağım’ dedi iki üç ay kaldım sonra geri dönmek zorunda kaldım” sözü, yine sosyal bağlamıyla "koca evinden baba evine dönülemeyeceği”’ şeklindeki şiarın da hâlâ yürürlükte olduğunu göstermektedir.

Katılımcılardan K.6'nın, 'Kimse kimseyi zorlamadı diyorum ya yeminliydim’ sözleri ve görüşme sırasında kadınların takındıkları 'sessizlik durumu' çok şeyi anlatır niteliktedir. "Sessiz kalmak onaylamaktır” düsturu kadınlar tarafından çoğu zaman çaresizliklerini çaresizce dile getirmek amacıyla benimsenip kullanılabilmektedir. Kadınlar sırf toplumda kabul gören hâkim statü olan "evli olmak” için kuma evliliklerini kabul etmektedirler. Kumalar eşleri tarafından bazen vaatlerle 'ikna' edilmişlerdir. Bu tablo yukarıdaki verileri destekleyici bir niteliktedir. 
Kadınların kuma olmayı kabul ettiği görülse de aslında ikna edilmişlerdir. Sadece ikna edilme tarzları farkl1lık göstermektedir.

\section{Sonuc}

Kuma evliliklerinin temel nedenlerinin başında gerek dünyada gerekse Türkiye'de derin etkiler gösteren ataerkil toplum yapısı gelmektedir. Söz konusu neden hem doğrudan hem de dolaylı olarak diğer faktörleri etkilemektedir. Aataerkil toplum yapısı genel olarak kadınlara yaklaşımın içeriğini tayin eden bir sosyo-kültürel çerçeve çizmektedir. Bu çalışmada kadınların beyanlarında da görüldüğü üzere başta sosyal çevre, kadınlara yönelik baskı oluşturmaktadır. Bunu evlilik kararlarının ailede alınması ve kuma evliliklerinin toplumsal olarak yaygın ve meşru hale gelmesi ile örneklendirebiliriz. Yine kadınların eğitimden uzak kalmasına yol açan zihinlerin üretilmesinde, ekonomik ve diğer alanlarda geri kalmalarında ataerkil zihniyet köklü bir biçimde etki etmektedir.

Nitekim elde edilen bulgular kadınların eğitim durumlarının kötü olduğunu göstermektedir. Bu etken kadınların erken yaşta evlenmelerine, eğitimsiz kalmalarına, emek sömürüsüne maruz kalmalarına sebep olmaktadır.

Ekonomik nedenler kuma evliliklerine ciddi derecede yön veren faktörlerden birisidir. Görüşülen kadınların çoğunun evlenmeden önce kalabalık ailelerde yaşamaları onlar açısından ekonomik açıdan dezavantajlı bir durumu teşkil etmektedir. Beslenme, barınma ve eğitime erişme noktasında bir engel olmaktadır. Verilerden de anlaşıldığı üzere özellikle yoksulluğun yön verdiği ekonomik zorluklar kadınların bu sorundan kuma şeklinde de olsa evlenerek kaçarak kurtulmak isteğini beraberinde getirmektedir. Fakat evlendikten sonra da başta aile içi çocuk, yaşlı bakımı yine tarla, bahçe ve diğer işlerde ücretsiz iş gücü olarak çalışmaya devam etmektedirler. Kadınlar evlenmeden önce ve sonra da emek sömürüsüne maruz kalmaktadırlar. Yani bir nevi yağmurdan kaçarken doluya tutulmaktadırlar. Kadınlar çocukları için çalışmak zorunda bırakılmaktadır. Burada çocukların da emekleri sömürülmektedir. Daha da önemlisi kuma kadınların evlilikleri yasal olmadığından üretim ve birikimden eş durumundan herhangi bir ekonomik pay alamamaktadırlar.

Erkek çocuk sahibi olmak geleneksel kültürde bir yanıyla soyun devamını sağlayan diğer yanıyla da erkeklik itibarını onaylayan bir olgudur. Bu olgu konumuz olan kuma evliliklerinin ortaya çıkmasında ve yaygınlaşmasında hâlâ bir etken olmakla birlikte katılımcıların ifadesi dikkate alındığında eski gücünü kaybetmektedir.

Kuma evliliklerinin önemli bir nedeni de sosyal çevrenin etkisidir. Nitekim kadınların kuma evlilikleri yapmaları noktasında başta aile olmak üzere, çevre etkisi, mahalle gibi baskı 
unsurları güçlü bir sosyal irade olarak iş görmektedirler. Nitekim katılımcıların çoğu bunun kendileri üzerinde ne denli etki yarattığını çeşitli vesilelerle dile getirmişlerdir. Geleneksel değerler bu evliliklerin meşrulaştırılmasında ve yeniden üretilmesinde ciddi roller üstlenmektedirler. Örneğin kadınların belli bir yaşa kadar evlenememeleri geleneksel zihinlerde bir kültürel sorun olarak kodlanmakta, bu da kadınların kumalığı evlilik için belki son çare olarak görmelerine yol açmaktadır. Çalışmamızda katılımcıların yaşları analiz edildiğinde, geleneksel evlenme yaşı ölçütlerini biraz geçen yani, toplumun beklenti ölçüsünde evlenmekte geç kalan kadınların, “evde kalma” korkusundan kuma evliliklerini kabul ettikleri görülmektedir.

\section{Yazarın Notu:}

Bu çalışma Muğla Sıtkı Koçman Üniversitesi Bilimsel Araştırma Projesi (BAP) tarafından 16/123 numara ile desteklenen “Türkiye'de Toplumsal Bir Sorun Olarak Kuma Evliliği: Hatay Örneği” başlıklı projeye dayanaktadır. BAP'a ve proje ekibine teşekkür ederiz.

\section{Kaynakça}

Acar-Savran, G (2004). “Marx'tan Delphy'e Bir Ufuk Taraması”: Beden ve Tarih: Diyalektik Bir Feminizm İçin. İstanbul: Kanat Yayınları.

Yılmaz, E., Tamam L., Bal U. (2015). Poligami ve Ruh Sağlığına Etkileri. Psikiyatride Güncel Yaklaşımlar, 7 (2) , 221-228. DOI: 10.5455/cap.20150325083302.

Douglas, R. White and Michael L. Burton (1988). "Causes of Polygyny: Ecology, Economy, Kinship, and Warfare". American Anthropologist, New Series, 90 (4), 871-887.

Ember, M. (1974). “Warfare, Sex Ratio, and Polygyny”. Ethnology, 13( 2), 197-206.

Ember, M., Ember, C. R., \& Low, B. S. (2007). Comparing explanations of polygyny. CrossCultural Research, 41(4), 428-440.

Engels, F. (2003). Ailenin, Özel Mülkiyetin ve Devletin Kökeni. (Çeviren: Kenan Somer) Seçme Yapıtlar, Cilt: III, Ankara: Sol Yayınları, (Birinci Baskı, Aralık 1979, 2003 yılında Eriş Yayınları tarafindan düzenlenmiştir).

Eyce, B. (2000). “Tarihten Günümüze Türk Aile Yapısı”. Selçuk Üniversitesi Sosyal Bilimler Meslek Yüksek Okulu Dergisi, Sayı: 4, 223-244.

Grossbard, A (1976). “An Economic Analysis of Polygyny: The Case of Maiduguri”. Current Anthropology, 17 (4), 701-707.

Güvenç, B. (1993). “Geleneklerden Kalıntılar: Başlık, Berdel, Kız-Kaçırma, Kuma ve Amca-Kızı Evliliği”. Kadın Araştırmaları Dergisi, Sayı: 1, 43-48. 
Kongar, E. (1993). Türk Toplum Bilimcileri 1, İstanbul: Remzi Kitabevi.

Lee, G. R. (1979). "Marital Structure and Economic Systems". Journal of Marriage and Family, $41(4), 701-713$.

Murdock, P.G. (1965). Social Structure. The Macmillian Company: New York.

Sayın, Ö. (2020). Aile Sosyolojisi. Ankara: Doğu Batı Yayınları.

Şen, H. (2014) Çocuk Gelinler: Evcilikten Evliliğe, Ankara: Detay Yayınları.

Tabak, A. (2008). “Endoktinoloji ve Metabolizma Polikliniğimizden Takipli Hastalarda Akraba Evliliği sıklı̆̆ı ve Akraba Evliliğini Etkileyen Faktörler”. Yayınlanmamış Uzmanlık Tezi, İstanbul.

Neuman, W.L (2010). Toplumsal Araştırma Yöntemleri: Nitel ve Nicel Yaklaşımlar, Çev: Özge S. I. Cilt (4. Bask1), İstanbul: Yayınodası.

Yasa, İ. (1962). Türkiye'de Kız Kaçırma Gelenekleri ve Bununla İlgili İdari Meseleler,. Ankara: Todaiye Yayını.

Yıldırım, A. ve Şimşek H. (2018). Sosyal Bilimlerde Nitel Araştırma Yöntemleri. Ankara: Seçkin.

İnternet Kaynakları

TBMM, Kadın Erkek Eşitliği Komisyonu, 2013, www.tuik.gov.tr, (Erişim tarihi 13.07.2020) 